$\begin{array}{ll}\text { Date: } & \text { March 3, } 2015 \\ \text { Draft for: } & \text { Journal of Membrane Science }\end{array}$

\title{
Reducing pumping energy by using different flow rates of high and low concentration solutions in reverse electrodialysis cells
}

\author{
Xiuping Zhu, Weihua He, Bruce E. Logan* \\ Department of Civil and Environmental Engineering, The Pennsylvania State University, University Park, \\ Pennsylvania 16802, United States \\ *Corresponding Author. Telephone: +1 814863 7908. Fax: +1 814863 7304. E-mail: blogan@psu.edu.
}

\begin{abstract}
Energy use for pumping affects both net energy recovery and operational costs of reverse electrodialysis (RED) systems. In order to reduce the energy needed for pumping, electrical performance and hydrodynamic power losses in a RED stack were investigated by simultaneously ( 2 to $140 \mathrm{~mL} / \mathrm{min}$ ) or independently varying the flow rates of the high concentration $(\mathrm{HC}, 35 \mathrm{~g} / \mathrm{L} \mathrm{NaCl})$ and low concentration ( $\mathrm{LC}, 0.35 \mathrm{~g} / \mathrm{L} \mathrm{NaCl})$ solutions. Power was not consistently reduced at lower flow rates due to trade-offs between increases in diffusion boundary layer resistance and decreases in solution resistance of the LC channels. The maximum net power output $(\sim 0.04 \mathrm{~W})$ was obtained with both $\mathrm{LC}$ and $\mathrm{HC}$ flow rates at $\sim 20 \mathrm{~mL} / \mathrm{min}$. Separately varying the flow rates of the HC and LC solutions indicated that the optimum flow rate of $\mathrm{HC}$ solution $(10 \mathrm{~mL} / \mathrm{min})$ was much lower than that of $\mathrm{LC}$ solution $(20 \mathrm{~mL} / \mathrm{min})$ due to the more substantial impact of the LC channel on power production. The use of these two optimized flow rates minimized hydrodynamic power losses (pumping energy) while producing comparable power to that achieved with the two higher flow rates $(50 \mathrm{~mL} / \mathrm{min}$ of both $\mathrm{HC}$ and LC solutions).

(C) 2015. This manuscript version is made available under the Elsevier user license http://www.elsevier.com/open-access/userlicense/1.0/
\end{abstract}




\section{Introduction}

Reverse electrodialysis (RED) is a sustainable energy technology that can be used to convert salinity gradient energy into electricity [1-3]. Salinity gradients that naturally exist between seawater and river water can be harnessed using RED to provide a large and renewable source of electricity. In theory, the global power production from salinity gradients could be as much as 1.4-2.6 TW, which is sufficient to meet the current worldwide demand for electrical power $(\sim 2$ TW) $[4,5]$. A RED stack consists of alternating cation (CEMs) and anion exchange membranes (AEMs). When solutions with different salinity flow on either side of these ion exchange membranes, Donnan potentials are created that drive cations from high concentration (HC) to low concentration (LC) channels through CEMs, and anions from HC to LC compartments through AEMs [6-8]. A large number of pairs of CEMs and AEMs are stacked together to increase the total potential $[9,10]$. At both ends of the stack, electrodes are used to convert the ionic flux into an electrical current, typically using a reversible redox reaction or by water splitting $[11,12]$.

The power output of a RED stack depends on the electromotive force (the total potential over the stack) and internal resistance that consists of both ohmic and non-ohmic resistances [13-15]. The ohmic resistance is produced by the membrane resistance and the LC and HC solution resistances. The main ohmic resistance is usually the solution resistance of the LC channels [9, 16]. The non-ohmic resistance consists of the electrical double layer and diffusion boundary layer resistances. Ion exchange membranes contain a high concentration of fixed charged groups attached to the polymer back bone, which attract counter ions with an opposite charge from the solution, and form an electrical double layer over the membrane surface $[16,17]$. The electrical 
double layer resistance arises from the interfacial ionic charge transfer in the solution phase through the electrical double layer to the membrane. When a current is applied, charge is transported through the membrane by counter ions (positive or negative), carried by both positive and negative ions in the bulk solution. The difference in ion transport number between the bulk solution and the membrane results in the formation of a diffusion boundary layer at the membrane surface $[16,18]$. Because the thickness of diffusion boundary layer (micrometers) is much larger than that of electrical double layer (nanometers), the diffusion boundary layer resistance is usually the dominant non-ohmic resistance $[16,19,20]$.

The improvement in electrical power by a RED stack that is obtained at higher flow rates is usually attributed to a decrease of diffusion boundary layer resistance $[7,9,10,19]$. However, the solution resistance in LC channels can also have a large contribution to the internal resistance of a RED stack. At lower flow rates, the solution conductivity in the LC channels will rapidly increase due to accumulated transport of more ions from the HC into the LC channels, which will reduce the ohmic resistance of the RED stack $[13,19]$. Therefore, it is possible that similar or better performance of the stack can be obtained at lower flow rates due to the trade-off between the increase of diffusion boundary layer resistance and the decrease of solution resistance in LC channels. Moreover, the flow rates not only affect the electrical performance of a RED process, but they also impact energy required to pump the HC and LC solutions through the RED stack. The pumping energy is an important part of the costs for RED operation, but it can reduced by pumping at lower flow rates [14, 21, 22]. Many studies have noted energy losses due to pressure drops in RED stacks $[13,14,19]$. However, using high flow rates of HC and LC solutions additionally impacts net energy production due to the energy needed to transport these solutions from the source to the RED stack site. Therefore, to make RED a commercially 
attractive renewable energy source, the electrical performance of the RED stack needs to be maximized while minimizing the flow rates of feed waters, in order to reduce energy losses due to both pressure drops in the stack and energy losses for pumping water to the site.

The flow rates of the HC and LC solutions fed to a RED stack are usually set to be the same $[3,23,24]$. However, the optimum flow rates of LC and HC solutions should be different due to the larger impact of solution and diffusion boundary layer resistances for the LC solution. Thus, it is likely that performance can be maintained at lower flow rates of $\mathrm{HC}$ solution than those of the LC solution. The reduction in the flow rate of the HC solution could reduce energy needed for pumping. Different flow rates of HC and LC solutions would create different pressures in adjacent channels, but pressure regulators can be used to adjust these pressures to avoid damage to the membranes.

In this study, the influences of different $\mathrm{HC}$ and LC flow rates were examined on electrical performance of a commercial RED stack as well as pumping energy. Initially, the effects were examined with the flow rates of $\mathrm{HC}$ and $\mathrm{LC}$ solutions simultaneously reduced from $140 \mathrm{~mL} / \mathrm{min}$ to $2 \mathrm{~mL} / \mathrm{min}$ to identify the region where there could be a trade-off between power output and pumping energy consumption. Then, the optimum flow rates of $\mathrm{HC}$ and LC solutions were determined by separately changing the flow rates of HC or LC solutions.

\section{Materials and methods}

\subsection{Reverse electrodialysis stack}

A commercial 10 cell pair RED cell (ED 64002-020, PCCell GmbH, Heusweiler, Germany) was used for all experiments. Both the anode and the cathode were titanium mesh coated with platinum and iridium (Ti/Pt-Ir), with a projected area of $64 \mathrm{~cm}^{2}(8 \mathrm{~cm} \times 8 \mathrm{~cm})$. The membrane 
stack was assembled with 11 cation exchange membranes (PC-SK) and 10 anion exchange membranes (PC-SA) provided by the manufacturer. The active membrane area was $64 \mathrm{~cm}^{2}(8 \mathrm{~cm}$ $\times 8 \mathrm{~cm}$ ) per membrane, for a total active membrane area of $0.13 \mathrm{~m}^{2}$. The thickness of spacers was $0.5 \mathrm{~mm}$ with a volume of porosity around $70 \%$. The anolyte and catholyte $(1 \mathrm{~L}, 35 \mathrm{~g} / \mathrm{L} \mathrm{NaCl})$ were mixed and recycled at $100 \mathrm{~mL} / \mathrm{min}$ to avoid large changes in $\mathrm{pH}$. The $\mathrm{HC}(35 \mathrm{~g} / \mathrm{L} \mathrm{NaCl})$ and LC $(0.35 \mathrm{~g} / \mathrm{L} \mathrm{NaCl})$ solutions flowed separately through the $\mathrm{HC}$ and LC channels of the stack in a single pass mode, at the indicated flow rates. Digital pressure gauges (DG25, Ashcroft Inc., Stratford, CT) were installed at the inlets and outlets of the HC and LC channels to monitor pressure changes. Pressure regulators (Hoffman open jaw screw compressor clamp, Humboldt Scientific Inc., Raleigh, NC) were added at the outlets of the HC and LC channels to adjust and obtain similar average pressures in the HC and LC channels in order to avoid membrane damage.

\subsection{Performance tests}

The open circuit voltages, maximum power densities, and maximum currents produced by the RED stack were obtained by conducting polarization tests. Galvanostatic polarization was performed using a multi-channel potentiostat (model 1470E, Solatron Analytical, Hampshire, England), with current scanned from 0 to the maximum (when the voltage of the RED stack became reversed) at a rate of $0.2 \mathrm{~mA} / \mathrm{s} . \mathrm{Ag} / \mathrm{AgCl}$ reference electrodes (BASi, West Lafayette, IN) were placed on either side of the membrane stack in the anolyte and catholyte to record the stack voltages. At least three polarization curves were recorded for each set condition. The open circuit voltage was determined from the vertical axis intercept of the polarization curves and the maximum current was obtained from the horizontal axis intercept of the polarization curves. The power density of the RED stack, which excluded electrode overpotentials, was calculated as [25]: 
$P_{\text {stack }}=\frac{U_{\text {stack }} \times I_{\text {stack }}}{A_{\text {mem }}}$

where $P_{\text {stack }}$ is the power density of the RED stack (W/m $/ \mathrm{m}^{2}$ membrane), $U_{\text {stack }}$ is the voltage of the membrane stack $(\mathrm{V}), I_{\text {stack }}$ is the scanned current $(\mathrm{A})$, and $A_{\text {mem }}$ is the total active membrane area of the stack $\left(\mathrm{m}^{2}\right)$.

The ohmic and non-ohmic resistances were distinguished using chronopotentiometry [13, 19, 22]. When a sudden change in electrical current is induced, the ohmic resistance causes a rapid change in stack voltage, while the response of the non-ohmic resistance is much slower and results in a gradual, time-dependent, change in stack voltage [22]. Therefore, the ohmic resistance was determined here from the sudden jump in voltage when an electrical current (50 $\mathrm{mA}$ and $100 \mathrm{~mA}$ ) was interrupted, while the non-ohmic resistance was calculated based on the remaining, time-dependent voltage change during the current interruption for about 2 min [13, 19]. The solution resistances in HC and LC channels were calculated as:

$$
R_{\mathrm{HC} / \mathrm{LC}}=\frac{n l}{\sigma A}
$$

where $n$ is the number of HC or LC channels $(n=10), l$ is the thickness of HC or LC channels $(0.05 \mathrm{~cm}), \sigma$ is the averaged inlet and outlet conductivities (in $\left.\mathrm{S} \mathrm{cm}^{-1}\right), A$ is the effective area available for charge transport $\left(\sim 44 \mathrm{~cm}^{2}\right)$ that was corrected for the spacer shadow effect by subtracting the projected area of the spacers $\left(\sim 20 \mathrm{~cm}^{2}\right)$ from the maximal membrane area available for charge transport $\left(64 \mathrm{~m}^{2}\right)$. The membrane resistance was obtained by subtracting HC and LC solution resistances from the ohmic resistance.

\subsection{Energy Calculations}

Electrical power output of the stack $\left(P_{\text {ele }}\right.$, in $\left.\mathrm{W}\right)$ was calculated by $P_{\text {ele }}=P_{\max } A_{\text {mem }}$, where $P_{\max }$ is the maximum power density of the stack obtained by polarization tests $\left(\mathrm{W} / \mathrm{m}^{2}\right.$ membrane) 
and $A_{\mathrm{mem}}$ is the total active membrane area of the stack $\left(\mathrm{m}^{2}\right)$. Hydrodynamic power losses $\left(P_{\mathrm{hydro}}\right.$, in $\mathrm{W}$ ) when $\mathrm{HC}$ and LC solutions flowed through the stack at different flow rates were calculated based on the pressure drops according to [7, 9]:

$$
P_{\text {hydro }}=\mathrm{Q}_{\mathrm{HC}} \Delta \mathrm{P}_{\mathrm{HC}}+\mathrm{Q}_{\mathrm{LC}} \Delta \mathrm{P}_{\mathrm{LC}}
$$

where $\mathrm{Q}_{\mathrm{HC}}$ and $\mathrm{Q}_{\mathrm{LC}}$ are the flow rates of $\mathrm{HC}$ and $\mathrm{LC}$ solutions $\left(\mathrm{m}^{3} / \mathrm{s}\right)$, and $\Delta \mathrm{P}_{\mathrm{HC}}$ and $\Delta \mathrm{P}_{\mathrm{LC}}$ are the pressure drops of the $\mathrm{HC}$ and LC channels $(\mathrm{Pa})$. The net power produced by the stack ( $P_{\text {net }}$, in $\left.\mathrm{W}\right)$ was obtained by subtracting the hydrodynamic power loss from the electrical power $\left(P_{\text {net }}=P_{\text {ele }}\right.$ $\left.P_{\text {hydro }}\right)$.

Pumping energy was also consumed to transport HC and LC solutions from the source to the RED stack. It is desirable to produce more power using less solution. Energy recovery $\left(E_{r}\right)$ is a suitable parameter to account for it, which was calculated as the ratio of electrical power output of the stack $\left(P_{\text {ele }}\right.$, in $\left.\mathrm{W}\right)$ relative to the total energy provided to the system $\left(X^{\text {in }}\right.$, in $\left.\mathrm{W}\right)$. The energy input $X^{\text {in }}$ was estimated from the change in the free energy due to complete mixing of the HC and LC solutions as [26, 27]:

$$
X^{i n}=R T \sum_{i}\left(Q_{H C} c_{i, H C}^{i n} \ln \frac{a_{i, H C}^{i n}}{a_{i, M}}+Q_{L C} c_{i, L C}^{i n} \ln \frac{a_{i, L C}^{i n}}{a_{i, M}}\right)
$$

where $R\left(8.314 \mathrm{~J} \mathrm{~mol}^{-1} \mathrm{~K}^{-1}\right)$ is the universal gas constant, $T(298 \mathrm{~K})$ the absolute temperature, $Q$ $\left(\mathrm{L} \mathrm{s}^{-1}\right)$ the flow rate of the solutions, $c(\mathrm{M})$ the molar concentration of ionic species $i$ in the solution, $a$ the activity of ionic species $i$ in the solutions obtained using OLI Analyzer Studio software (OLI Systems Inc., Cedar Knolls, NJ), and the subscripts HC, LC, and M indicates the high concentration, low concentration, and mixed solutions.

\section{Results and discussion}

\subsection{Performance with identical LC and HC flow rates}


observations, the three regions were defined as: the diffusion boundary layer resistance dominating region (Region I); the constant power output region (due to offsetting diffusion boundary layer and LC solution resistances) (Region II); and the electromotive force dominating region (Region III). These results demonstrated that the power output of a RED stack is not always improved by using high flow rates, as power production depends on which resistances predominate at a given flow rate.

The maximum current $\left(I_{\max }\right)$ is mostly affected by the total resistance, as it has only a first order relationship with the voltage compared to a second order dependence on the voltage for $P_{\max }$. As a result, the changes in $I_{\max }$ generally followed those of $P_{\max }$ in Regions I, but in Region II and III the maximum currents increased with decreased flow rates until only the very lowest flow rates were tested (Fig. 1C).

\subsection{Net power and energy recovery with identical $H C$ and LC flowrates}

The flow rates not only affect power production, they also influence net energy output. The pressure drops through $\mathrm{HC}$ and LC channels decreased linearly with flow rates from $5.5 \mathrm{kPa}$ to nearly $0 \mathrm{kPa}$ (Fig. 1D). The pressure drop through the LC channel was slightly lower than that through $\mathrm{HC}$ channel, which could be due to the differences in roughness of the two sides of ion exchange membranes. The hydrodynamic power loss calculated using Eq. 3, also significantly declined at lower flow rates (Fig. 1E). When hydrodynamic power loss was subtracted from electrical power output, the net power output of the RED stack was shown to be highest $(\sim 0.04$ W) at middle flow rates of $20 \sim 50 \mathrm{~mL} / \mathrm{min}$ (Fig. 1E).

Energy recovery is another important aspect of RED stack operation as this reflects how much energy can be extracted from the feed water used in the process [28, 29]. Higher energy 


\subsection{Performance with different flow rates for the LC solution}

In order to investigate if different flow rates can be used for $\mathrm{HC}$ and $\mathrm{LC}$ solutions, the flow rates of LC solution were gradually decreased from $50 \mathrm{~mL} / \mathrm{min}$ to $2 \mathrm{~mL} / \mathrm{min}$, while the flow rate of the $\mathrm{HC}$ solution was fixed at $50 \mathrm{~mL} / \mathrm{min}$. The changes of open circuit voltage (Fig. 2A), maximum power density (Fig. 2B), and maximum current (Fig. 2C) with decreased LC flow rates were similar to those obtained with identical flow rates, which indicated that the performance of a RED stack was mainly determined by the LC flow rate. Based primarily on the power output, a minimum flow rate for power production was about $20 \mathrm{~mL} / \mathrm{min}$.

Analysis of the pressure drops and net power production also support an optimal LC flow rate of $\sim 20 \mathrm{~mL} / \mathrm{min}$ (residence time of $1.6 \mathrm{~min}$, linear velocity of $5 \mathrm{~cm} / \mathrm{min}$ ) for this system. The pressure drop of LC channel linearly decreased with flow rates, while that of HC channel was similar due to the fixed flow rate (Fig. 2D). There were no observed physical changes in the membranes, as the similar average pressures were used in the $\mathrm{HC}$ and LC channels, although the 
pressure drops were slightly different. The highest net power output $(\sim 0.04 \mathrm{~W})$ was obtained at LC flow rate of $20 \mathrm{~mL} / \mathrm{min}$ (Fig. 2E). The energy recovery increased from $2 \%$ to $5 \%$ when the flow rate decreased from $50 \mathrm{~mL} / \mathrm{min}$ to $20 \mathrm{~mL} / \mathrm{min}$, due to the reduced energy input (Fig. 2F).

\subsection{Performance with different flow rates for the HC solution}

To examine if a lower flow rate could be used for the $\mathrm{HC}$ solution, the flow rates of $\mathrm{HC}$ solution gradually decreased from $50 \mathrm{~mL} / \mathrm{min}$ to $2 \mathrm{~mL} / \mathrm{min}$ while the flow rates of the LC solution was fixed at $50 \mathrm{~mL} / \mathrm{min}$. The changes of open circuit voltage (Fig. 3A), maximum power density (Fig. 3B), and maximum current (Fig. 3C) were different from those previously obtained with identical HC and LC flow rates, or when only the flow rate of the LC solution was decreased. There was very little change in the open circuit voltage for all flow rates (Fig. 3A). The maximum power densities and currents were nearly constant, until the flow rate was decreased to $10 \mathrm{~mL} / \mathrm{min}$ or less (Fig. 3B and 3C). These results indicated that the loss of ions and change in the $\mathrm{HC}$ solution did not greatly impact power production until the flow rate was quite low.

Examination of the pressure drops and net power production also suggested an optimum HC flow rate of $\sim 10 \mathrm{~mL} / \mathrm{min}$ (residence time of $3.2 \mathrm{~min}$, linear velocity of $2.5 \mathrm{~cm} / \mathrm{min}$ ). The pressure drop for the LC solution slightly varied, but the pressure drop for the HC solution decreased with the flow rates as expected (Fig. 3D). Similarly, there was no observed physical changes in the membranes due to the close average pressures in the HC and LC channels. The highest net power output $(\sim 0.04 \mathrm{~W})$ was shown at $\mathrm{HC}$ flow rate of $10 \mathrm{~mL} / \mathrm{min}$ (Fig. 3E), and the energy recovery increased from $2 \%$ to $10 \%$ when the flow rate of $\mathrm{HC}$ solution decreased from $50 \mathrm{~mL} / \mathrm{min}$ to 10 
$\mathrm{mL} / \mathrm{min}$ (Fig. 3F). Thus, the optimum flow rate of $\mathrm{HC}$ solution $(10 \mathrm{~mL} / \mathrm{min})$ was estimated to be about half of that of LC solution $(20 \mathrm{~mL} / \mathrm{min})$.

\subsection{Performance using the optimized LC and HC flow rates}

The performance of the RED stack at optimized flow rates of $10 \mathrm{~mL} / \mathrm{min}$ for $\mathrm{HC}$ solution and $20 \mathrm{~mL} / \mathrm{min}$ for LC solution (HC10/LC20) was compared to that with both solutions at a flow rate of $50 \mathrm{~mL} / \mathrm{min}$ (HC50/LC50). Although the open circuit voltage using these two different flow rates $(1.58 \mathrm{~V})$ was a little lower than that at higher flow rates $(1.70 \mathrm{~V})$, the maximum power density was similar $\left(0.28 \mathrm{~W} / \mathrm{m}^{2}\right.$ membrane $)$ for these two cases, and the maximum current at optimized flow rates $(123 \mathrm{~mA})$ was even a little higher than that at higher flow rates (108 $\mathrm{mA})$ due to decreased internal resistance at optimized flow rates (Fig. 4).

The internal resistance was further investigated by chronopotentiometry method to distinguish the ohmic and non-ohmic resistance (Fig. 5A). Compared to higher flow rates (HC50/LC50, $17 \Omega$ ), the total internal resistance at optimized flow rates (HC10/LC20, 14 $\Omega$ ) was reduced, in agreement with polarization tests. The decrease of internal resistance was attributed to the large decline of ohmic resistance from $14 \Omega$ to $10 \Omega$, although the non-ohmic resistance slightly increased from $3 \Omega$ to $4 \Omega$ likely due to the larger diffusion boundary layer resistance. The obvious decrease of ohmic resistance could result from ion transfer and accumulation in the LC channels at lower flow rates. The LC solution resistance decreased from $11 \Omega$ (HC50/LC50) to $7 \Omega(\mathrm{HC} 10 / \mathrm{LC} 20)$ with similar $\mathrm{HC}$ solution resistance of $0.2 \Omega$ and membrane resistance of 3 $\Omega$. The hydrodynamic power loss $(0.5 \mathrm{~mW})$ was greatly reduced by using the lower flow rates, compared to the power loss with the two higher flow rates $(4.5 \mathrm{~mW})$ (Fig. 5B). The energy recovery also increased from 3\% (HC50/LC50) to 8\% (HC10/LC20) (Fig. 5C). 


\section{Acknowledgments}

We thank Marta C. Hatzell for providing helpful suggestions on the experiments and other comments. This research was supported by Department of Energy Cooperative Agreement DEEE0005750.

\section{References}

[1] B.E. Logan, M. Elimelech, Membrane-based processes for sustainable power generation using water, Nature 488 (2012) 313-319. 
[2] G.Z. Ramon, B.J. Feinberg, E.M.V. Hoek, Membrane-based production of salinity-gradient power, Energ. Environ. Sci. 4 (2011) 4423-4434.

[3] J.W. Post, H.V.M. Hamelers, C.J.N. Buisman, Energy recovery from controlled mixing salt and fresh water with a reverse electrodialysis system, Environ. Sci. Technol. 42 (2008) 57855790 .

[4] G.L. Wick, W.R. Schmitt, Prospects for renewable energy from the sea, Mar. Technol. Soc. J. 11 (1977) 16-21.

[5] J.D. Isaacs, R.J. Seymour, The ocean as a power resource, Int. J. Environ. Stud. 4 (1973) 201205.

[6] P. Dlugolecki, K. Nymeijer, S. Metz, M. Wessling, Current status of ion exchange membranes for power generation from salinity gradients, J. Membr. Sci. 319 (2008) 214-222. [7] J. Veerman, M. Saakes, S.J. Metz, G.J. Harmsen, Electrical power from sea and river water by reverse electrodialysis: a first step from the laboratory to a real power plant, Environ. Sci. Technol. 44 (2010) 9207-9212.

[8] E. Guler, R. Elizen, D.A. Vermaas, M. Saakes, K. Nijmeijer, Performance-determining membrane properties in reverse electrodialysis, J. Membr. Sci. 446 (2013) 266-276.

[9] J. Veerman, M. Saakes, S.J. Metz, G.J. Harmsen, Reverse electrodialysis: Performance of a stack with 50 cells on the mixing of sea and river water, J. Membr. Sci. 327 (2009) 136-144. [10] P. Dlugolecki, A. Gambier, K. Nijmeijer, M. Wessling, Practical potential of reverse electrodialysis as process for sustainable energy generation, Environ. Sci. Technol. 43 (2009) 6888-6894.

[11] J. Veerman, M. Saakes, S.J. Metz, G.J. Harmsen, Reverse electrodialysis: evaluation of suitable electrode systems, J. Appl. Electrochem. 40 (2010) 1461-1474.

[12] O.S. Burheim, F. Seland, J.G. Pharoah, S. Kjelstrup, Improved electrode systems for reverse electro-dialysis and electro-dialysis, Desalination 285 (2012) 147-152.

[13] D.A. Vermaas, M. Saakes, K. Nijmeijer, Doubled power density from salinity gradients at reduced intermembrane distance, Environ. Sci. Technol. 45 (2011) 7089-7095.

[14] D.A. Vermaas, M. Saakes, K. Nijmeijer, Power generation using profiled membranes in reverse electrodialysis, J. Membr. Sci. 385 (2011) 234-242.

[15] D.A. Vermaas, E. Guler, M. Saakes, K. Nijmeijer, Theoretical power density from salinity gradients using reverse electrodialysis, Energy Procedia 20 (2012) 170-184.

[16] P. Dlugolecki, P. Ogonowski, S.J. Metz, M. Saakes, K. Nijmeijer, M. Wessling, On the resistances of membrane, diffusion boundary layer and double layer in ion exchange membrane transport, J. Membr. Sci. 349 (2010) 369-379.

[17] H. Strathmann, Ion-exchange membrane separation processes, in: Membrane Science and Technology, Elsevier, 2004.

[18] J.J. Krol, M. Wessling, H. Strathmann, Concentration polarization with monopolar ion exchange membranes: current-voltage curves and water dissociation, J. Membr. Sci. 162 (1999) 145-154.

[19] D.A. Vermaas, M. Saakes, K. Nijmeijer, Enhanced mixing in the diffusive boundary layer for energy generation in reverse electrodialysis, J. Membr. Sci. 453 (2014) 312-319.

[20] A.J. Bard, L.R. Faulkner, Electrochemical Methods: Fundamentals and Applications, Wiley, New York, 2000.

[21] S. Pawlowski, J.G. Crespo, S. Velizarov, Pressure drop in reverse electrodialysis:

Experimental and modeling studies for stacks with variable number of cell pairs, J. Membr. Sci. 462 (2014) 96-111. 
[22] D.A. Vermaas, M. Saakes, K. Nijmeijer, Early detection of preferential channeling in reverse electrodialysis, Electrochim. Acta 117 (2014) 9-17.

[23] D.A. Vermaas, J. Veerman, M. Saakes, K. Nijmeijer, Influence of multivalent ions on renewable energy generation in reverse electrodialysis, Energ Environ Sci 7 (2014) 1434-1445. [24] J. Veerman, R.M. de Jong, M. Saakes, S.J. Metz, G.J. Harmsen, Reverse electrodialysis: Comparison of six commercial membrane pairs on the thermodynamic efficiency and power density, J. Membr. Sci. 343 (2009) 7-15. [25] M.C. Hatzell, I. Ivanov, R.D. Cusick, X.P. Zhu, B.E. Logan, Comparison of hydrogen production and electrical power generation for energy capture in closed-loop ammonium bicarbonate reverse electrodialysis systems, Phys. Chem. Chem. Phys. 16 (2014) 1632-1638. [26] J.Y. Nam, R.D. Cusick, Y. Kim, B.E. Logan, Hydrogen generation in microbial reverseelectrodialysis electrolysis cells using a heat-regenerated salt solution, Environ. Sci. Technol. 46 (2012) 5240-5246.

[27] X.P. Zhu, W.L. Yang, M.C. Hatzell, B.E. Logan, Energy recovery from solutions with different salinities based on swelling and shrinking of hydrogels, Environ. Sci. Technol. 48 (2014) 7157-7163.

[28] D.A. Vermaas, J. Veerman, N.Y. Yip, M. Elimelech, M. Saakes, K. Nijmeijer, High efficiency in energy generation from salinity gradients with reverse electrodialysis, ACS Sustainable Chem. Eng. 1 (2013) 1295-1302.

[29] N.Y. Yip, D.A. Vermaas, K. Nijmeijer, M. Elimelech, Thermodynamic, energy efficiency, and power density analysis of reverse electrodialysis power generation with natural salinity gradients, Environ. Sci. Technol. 48 (2014) 4925-4936. 
Figures:
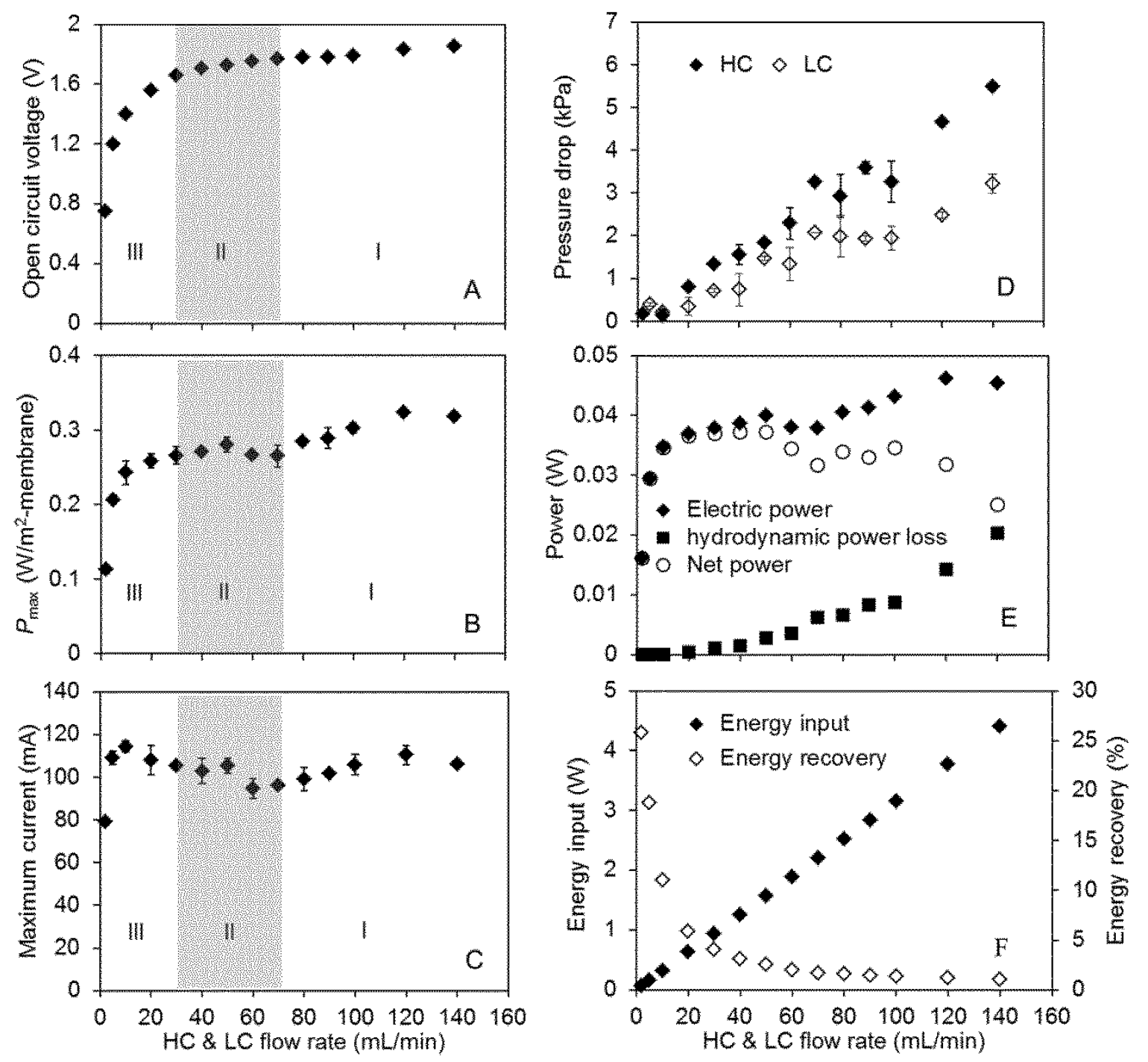

Fig. 1. (A) Open circuit voltage, (B) maximum power density, (C) maximum current, (D) pressure drops of HC and LC solutions, (E) electrical power, hydrodynamic power loss, and net power, and $(\mathrm{F})$ energy input and energy recovery of the RED stack when the flow rates of HC and LC solutions simultaneously decreased from $140 \mathrm{~mL} / \mathrm{min}$ to $2 \mathrm{~mL} / \mathrm{min}$. 

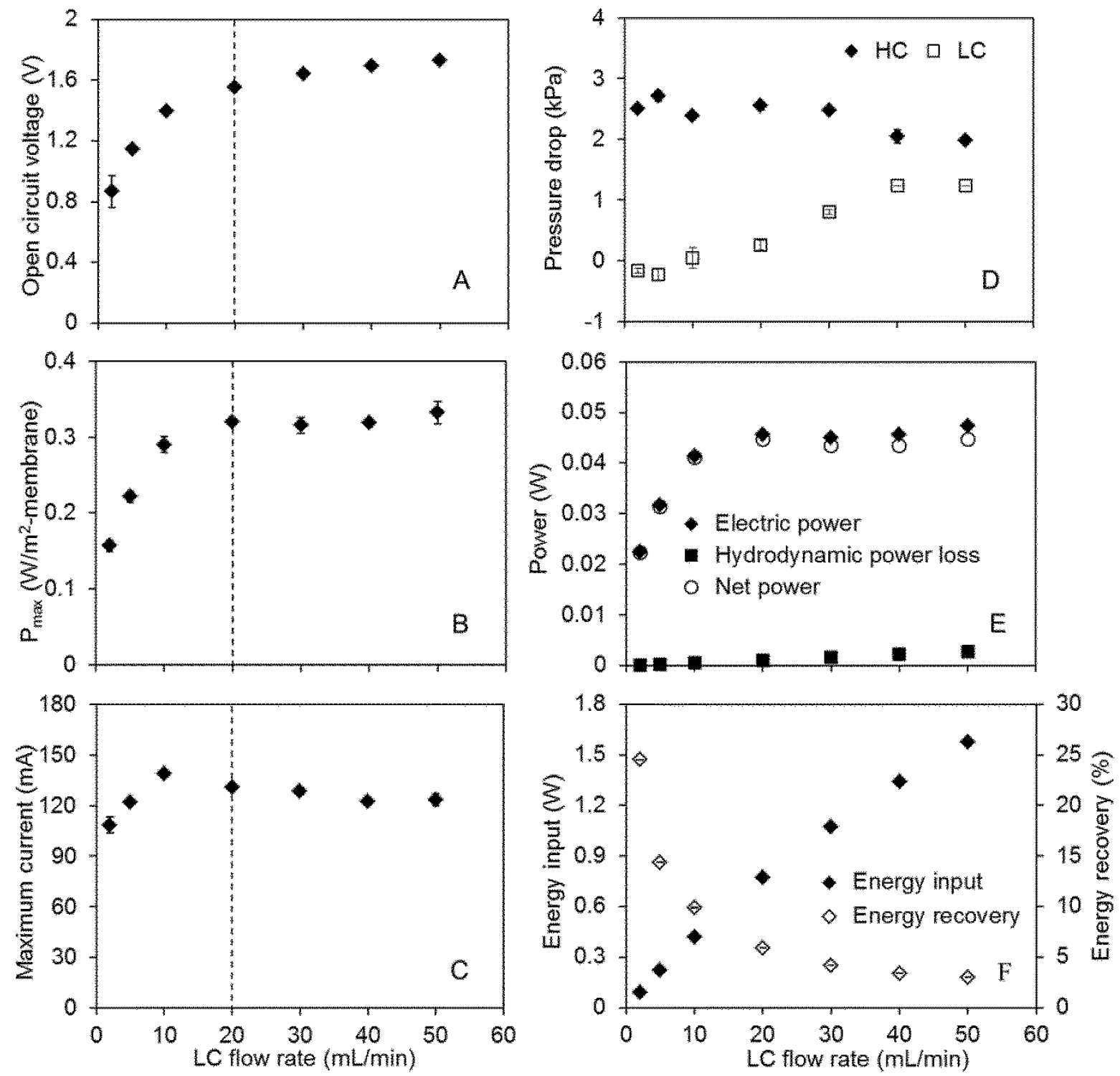

Fig. 2. (A) Open circuit voltage, (B) maximum power density, (C) maximum current, (D) pressure drops of HC and LC solutions, (E) electrical power, hydrodynamic power loss, and net power, and $(\mathrm{F})$ energy input and energy recovery of the RED stack when the flow rates of LC solution decreased from $50 \mathrm{~mL} / \mathrm{min}$ to $2 \mathrm{~mL} / \mathrm{min}$ and the flow rate of $\mathrm{HC}$ solution was 50 $\mathrm{mL} / \mathrm{min}$. 

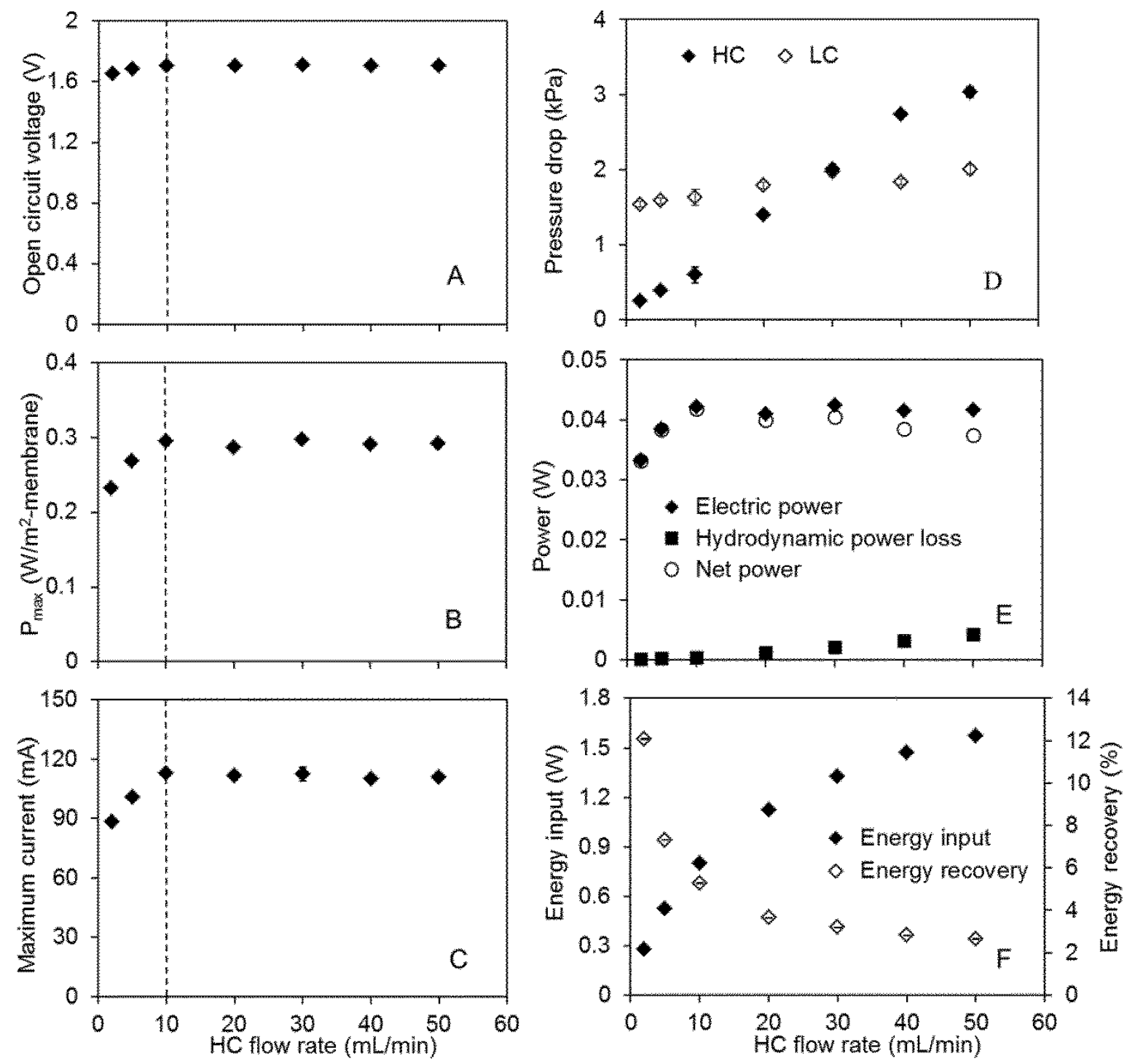

Fig. 3. (A) Open circuit voltage, (B) maximum power density, (C) maximum current, (D) pressure drops of $\mathrm{HC}$ and LC solutions, (E) electrical power, hydrodynamic power loss, and net power, and $(\mathrm{F})$ energy input and energy recovery of the RED stack when the flow rates of HC solution decreased from $50 \mathrm{~mL} / \mathrm{min}$ to $2 \mathrm{~mL} / \mathrm{min}$ and the flow rate of LC solution was 50 $\mathrm{mL} / \mathrm{min}$. 

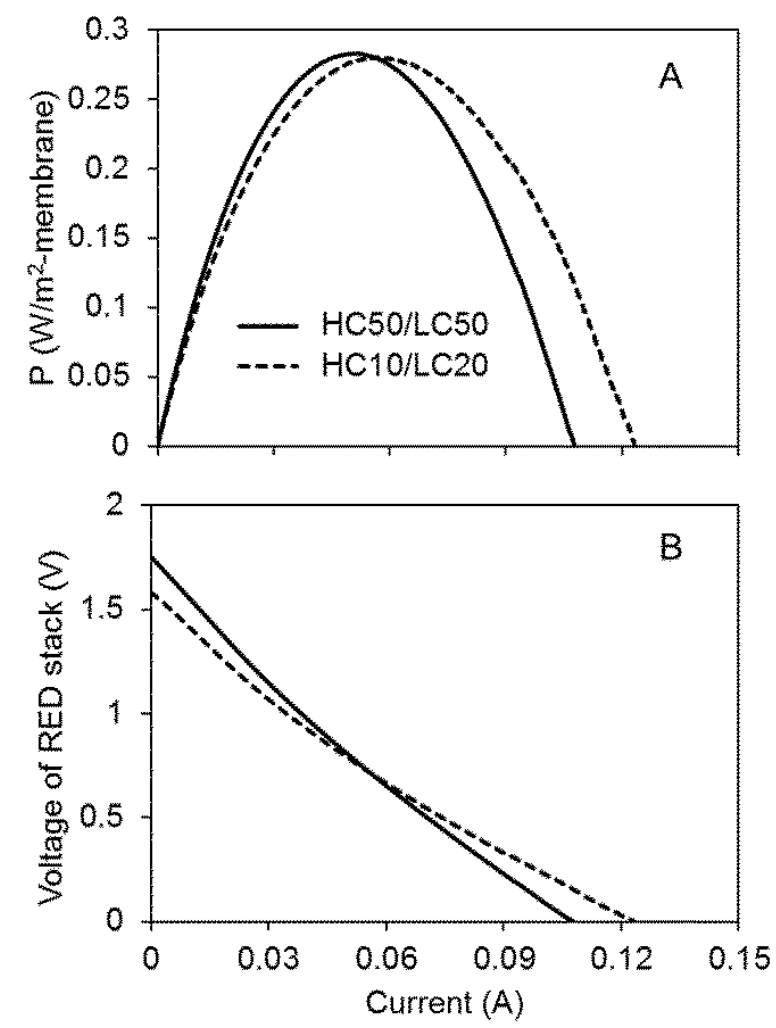

Fig. 4. (A) Power density curves and (B) polarization curves of the RED stack when the flow rates of both $\mathrm{HC}$ and $\mathrm{LC}$ solutions were $50 \mathrm{~mL} / \mathrm{min}$ (HC50/LC50) and the flow rate of $\mathrm{HC}$ solution was $10 \mathrm{~mL} / \mathrm{min}$ with the flow rate of $20 \mathrm{~mL} / \mathrm{min}$ for LC solution (HC10/LC20). 

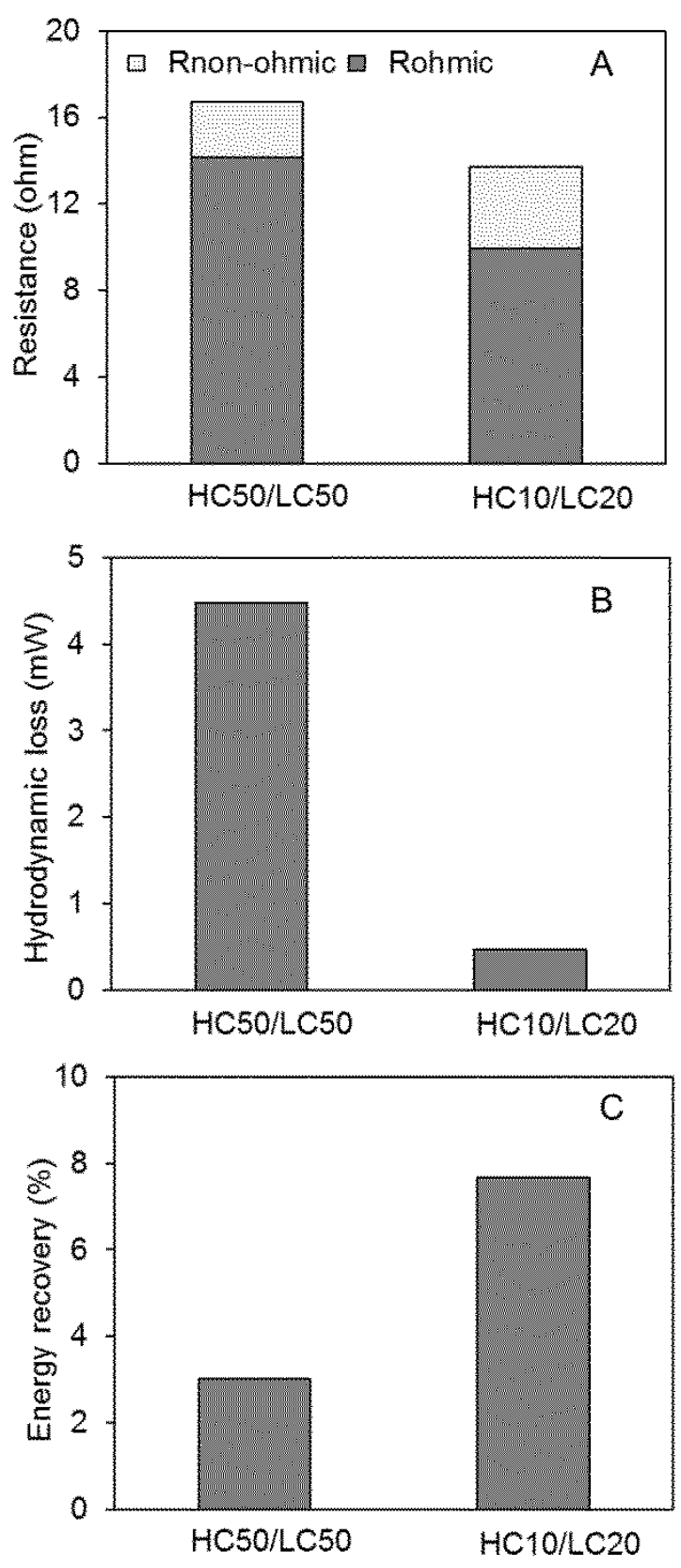

Fig. 5. (A) Internal resistances including ohmic resistances and non-ohmic resistances, (B) hydrodynamic power loss, and (C) energy recovery of the RED stack when the flow rates of both $\mathrm{HC}$ and LC solutions were $50 \mathrm{~mL} / \mathrm{min}$ (HC50/LC50) and the flow rate of HC solution was 10 $\mathrm{mL} / \mathrm{min}$ with the flow rate of $20 \mathrm{~mL} / \mathrm{min}$ for LC solution (HC10/LC20). 


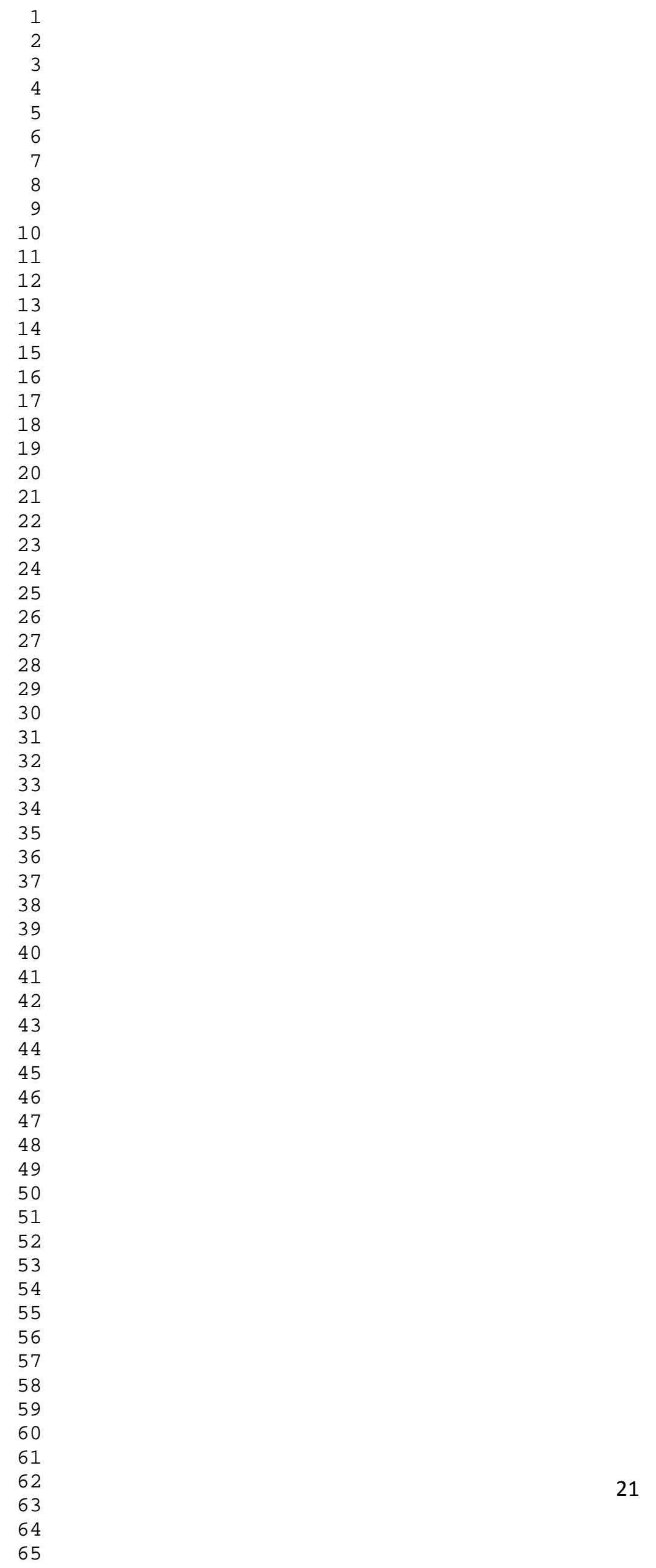

